\title{
Evolving strategy and long-term surgical outcome of mitral valve repair in congenital mitral valve stenosis
}

\author{
Eva Delmo Walter, ${ }^{*}$ Roland Hetzer \\ From 23rd World Congress of the World Society of Cardio-Thoracic Surgeons \\ Split, Croatia. 12-15 September 2013
}

\section{Background}

Having collected a large series of congenital mitral stenosis we studied the operative results and long-term outcome of our evolving mitral valve (MV) repair techniques performed to correct this lesion.

\section{Methods}

Between 1986 and 2012, 137 infants and children (mean age $4.1 \pm 5.0$ (range 1 month to 16.8 years) underwent surgical correction of congenital mitral stenosis (CMS). In 48 patients, CMS is involved in Shone's anomaly. The typical congenital MS (Type I) was seen in 56 patients., hypoplastic MV (Type II) in 15 patients, supravalvar mitral ring (Type III in 48 patients, parachute MV (Type IV) in 10 patients and hammock valve (Type IV) in 8 patients.

\section{Results}

MV repair was performed using commissurotomy, division of chordae tendinae, papillary muscle splitting and fenestration, and resection of mitral ring, applied according to the presenting morphology in patients with either previously corrected or concomitant correction of the leftsided obstructive lesions. Postoperative echocardiography showed absence of MV stenosis and immediate improvement of symptoms, except in a 3-month-old infant who died 18 days postoperatively due to myocardial failure. During the 24-year follow-up, 23 patients underwent repeat MV repair and 3 underwent MV replacement after failed attempts at repair. Mean duration of follow-up was $17.5 \pm 1.5$ years. Freedom from reoperation was $97.6 \pm$ $2.4 \%, 89.3 \pm 5.1 \%$, and $52.8 \pm 11.8 \%$, at 30 days, 1 and

\footnotetext{
* Correspondence: delmo-walter@dhzb.de

Cardiothoracic Surgery, Deutsches Herzzentrum Berlin, Berlin, Germany
}

15 years postoperatively, respectively Cumulative survival rate was $97.6 \pm 2.4 \%, 92.3 \pm 4.3 \%$, and $70.3 \pm 8.9 \%$, at 30 days, 1 and 15 years postoperatively, respectively Mortality unrelated to valve repair accounted for 9 (20\%) deaths.

\section{Conclusions}

Long-term functional outcome of mitral valve repair in children with CMS is satisfactory. Repeat MV repair and/ or replacement may be deemed necessary during the course of follow-up.

Published: 11 September 2013

doi:10.1186/1749-8090-8-S1-O273

Cite this article as: Delmo Walter and Hetzer: Evolving strategy and longterm surgical outcome of mitral valve repair in congenital mitral valve stenosis. Journal of Cardiothoracic Surgery 2013 8(Suppl 1):O273.

Submit your next manuscript to BioMed Central and take full advantage of:

- Convenient online submission

- Thorough peer review

- No space constraints or color figure charges

- Immediate publication on acceptance

- Inclusion in PubMed, CAS, Scopus and Google Scholar

- Research which is freely available for redistribution

Submit your manuscript at www.biomedcentral.com/submit C Biomed Central 